Relations industrielles

Industrial Relations

\title{
Shadows Over Arbitration
}

\section{H. D. Woods}

Volume 33, numéro 4, 1978

URI : https://id.erudit.org/iderudit/028916ar

DOI : https://doi.org/10.7202/028916ar

Aller au sommaire du numéro

\section{Éditeur(s)}

Département des relations industrielles de l'Université Laval

ISSN

0034-379X (imprimé)

1703-8138 (numérique)

Découvrir la revue

Citer cet article

Woods, H. D. (1978). Shadows Over Arbitration. Relations industrielles / Industrial Relations, 33(4), 685-697. https://doi.org/10.7202/028916ar
Résumé de l'article

The author presents what he believes to be an excessive dose of public intervention in the relationship between labour and management and more particularly in the field of arbitration.
Tous droits réservés (C Département des relations industrielles de l'Université Laval, 1978
Ce document est protégé par la loi sur le droit d'auteur. L'utilisation des services d'Érudit (y compris la reproduction) est assujettie à sa politique d'utilisation que vous pouvez consulter en ligne.

https://apropos.erudit.org/fr/usagers/politique-dutilisation/ 


\title{
COMMENTAIRES
}

\section{SHADOWS OVER ARBITRATION}

\author{
H. D. Woods
}

The author presents what he believes to be an excessive dose of public intervention in the relationship between labour and management and more particularly in the field of arbitration.

A meeting of the National Academy of Arbitrators in Toronto justifies a closer look at Canadian policy and experience in industrial relations than is usually undertaken in these sessions. This is in no way to be taken as a criticism of either earlier programs or program committees, the former of which are worthy of praise and the latter of commendation. But Canadian experiments in public policy in labour relations have certain unique characteristics which are perhaps not too well known and understood in the United States by practitioners of the art of arbitration, and even by some scholars who have taken an analytical approach to the work of the trade. An examination of a foreign industrial relations system reveals truths about that system and serves to put into better perspective the more familiar industrial relations system of the home territory of the investigator. Particularly it forces recognition and re-examination of inarticulate premises which lurk in the background but are seldom challenged until international comparisons expose them to view. In my own experience, the more I learned about the industrial relations systems of the United States and one or two underdeveloped countries in which I worked, the more I was forced to question the validity of unchallenged assumptions upon which the Canadian system was constructed. With this in mind, I propose

* WOODS, H. D., Professor, McGill University; President, National Academy of Arbitrators.

** Reprinted by permission from ARBITRATION-1977, Proceedings of the Thirtieth Annual Meeting, National Academy of Arbitrators, copyright c 1978 by The Bureau of National Affairs, Inc., Washington, D.C. 20037 
to look at some important Canadian experiments in public policy regarding arbitration.

Canadian authorities have shown a marked pre-occupation with industrial peace as a goal, and there are important Canadian innovations in legislative control of industrial relations. Indeed of the eleven political jurisdictions, the ten provinces and the federal authority, only one, Saskatchewan, has a legal system which is in most respects similar to that of the United States. All the other jurisdictions have departed from the American model by the imposition of compulsory conciliation of negotiation or interest disputes, and by a prohibition by law of the work stoppage during the term of an agreement, coupled with a legal requirement to refer unresolved disputes to arbitration if necessary.

My thesis is that while Canadian unions and management appear to be operating under an arbitration system very similar to that of the United States, in fact they are carrying out the requirements of the law, whereas in the United States the parties engage in arbitration because they have agreed to do so for the resolution of disputes arising under the agreement they have negotiated. In the United States, the arbitration clause is the instrument of enforcement of the agreement and is a substitute for the work stoppage. This fundamental difference is not usually revealed in collective agreements. Usually American agreements do contain no-strike and no-lockout clauses. So do Canadian agreements. Usually American agreements contain a grievance procedure and a provision for arbitration of unresolved grievance disputes. The same is true of Canadian agreements. In other words, on the face of it Canadian and American agreements appear to make the same provisions for dealing with disputes arising during the life of an agreement concerning its interpretation or application. But there is the very important difference that in the Canadian case these provisions are required by law and in the American case they are the result of voluntarism. It is my contention that this difference is a significant one; that it has influenced the tone and character of arbitration, and that the process of collective bargaining has also been affected. Finally I believe that because arbitration is a statutory requirement, resistance to an extension of state intervention has been weakened in Canada, and certain trends in public policy suggest that arbitration as an instrument for the resolution of disputes arising during the term of an agreement is slipping out of the hands of the contracting parties and into the hands of state agencies.

It is difficult to prove this thesis, and in a sense I am opening up an area for further research which seems to be needed. But an examination of the legislative provisions for labour arbitration in Canada is a first step 
toward an understanding of the course of public policy in contract dispute resolution.

In a luncheon address a lot of history is intolerable, a modest amount can be boring, but a little may be necessary, and I hope, can be interesting. As early as 1903 the Canadian federal government, following a disturbing railway strike, introduced a compulsory arbitration bill applicable to railway disputes. ${ }^{1}$ At that time the Trades and Labour Congress of Canada and some of the unions were supporting the principle of compulsory arbitration. Under pressure from the international railway unions, and the influence of the American Federation of Labor, Parliament removed compulsory arbitration from the law and it emerged as a compulsory concilation act. In 1907 the Industrial Disputes Investigation Act ${ }^{2}$ imposed both compulsory conciliation boards and a suspension of the strike, or a cooling-off period on the parties in disputes in public utilities and mines.

While this was a federal law, because of the uncertainty at the time regarding provincial and federal jurisdictions, it was applied without distinction in utilities and mines. The uncertainty was removed in 1923 by a ruling of the Privy Council in Britain, ${ }^{3}$ at that time still the final court of appeal in Canadian cases. The basis of the present balkanization of Canadian labour relations jurisdictions was laid. The federal government's jurisdiction was reduced to a very limited coverage and the provincial sway over the entire manufacturing, mining, commercial, and construction sectors was confirmed.

The period of the 1930's saw the rise of «Wagnerism» in the United States and the arrival of general required recognition of unions, and compulsory collective bargaining in that country. Canada was slow to follow, although a number of provinces in 1937, under pressure from the unions, introduced weak versions of the Wagner Act, usually without enforcement machinery such as labour relations boards.

The second world war led to at least three major changes in Canadian industrial relations policy. First, under the emergency powers in the British North America Act, the document in Canada which passes for a written constitution, authority shifted to the federal government away from the provinces. Secondly, the Wagner principle of compulsory

\footnotetext{
Railway Labour Disputes Act, 1903.

2 Full Title - An Act to Aid in the Prevention and Settlement of Strikes and Lockouts in Mines and Industries Connected with Public Utilities.

3 Toronto Electric Commissioners v. Snider, Appeal Cases, 1925.
} 
recognition and collective bargaining was imported from the United States and combined with the existing compulsory conciliation. Finally, compulsory arbitration of disputes arising during the life of an agreement was incorporated into the law.

In 1943 British Columbia's rather anaemic Industrial Conciliation and Arbitration Act of 1937 was beefed up by compelling recognition and collective bargaining. It also imposed a complicated form of compulsory conciliation during negotiations. In the same year Ontario ${ }^{4}$ introduced Wagner principles, provided for certification, and established a labour court to carry out the functions normally associated with a labour relations board. It was the first administrative body in Canada charged with the enforcement of broadly conceived labour law.

The third change, and the one of particular interest to arbitrators, was the introduction of compulsory arbitration of grievance disputes. As early as 1940 in a policy document ${ }^{5}$ the federal government issued a statement of intent. In this it was stated that every collective agreement should provide machinery for the settlement of disputes arising out of the agreement, and for its renewal or revision. But while this policy was not enforceable, it became so in 1944 when the Canadian government finally got around to establishing a general war-time labour relations policy. ${ }^{6}$ Thus, all three major policy changes were brought together. The system was centralized and unified under federal control; the Canadian system of compulsory conciliation and suspension of the strike was combined with the American system of compulsory collective bargaining; and arbitration of grievance disputes was imposed by law.

This was the essence of the system for the rest of the war and post-war emergency period. The federal government's special authority, however, expired with the end of the emergency and the provinces wasted no time moving in to fill the vacuum. And it is interesting to note that all jurisdictions retained as a basic structure the Wagner Act system which had come to Canada as a war-time measure. But that was the extent of complete uniformity continuing into the 1950's. However, two other war-time experiments were continued by all jurisdiction but Saskatchewan. These were compulsory conciliation boards for negotiation disputes and, of special interest to the members of the Academy, compulsory arbitration of disputes arising during the term of an agreement. So the experiment of compulsory arbitration of rights

\footnotetext{
Ontario Collective Bargaining Act, 1943.
}

Privy Council Order, 2685, 1940. 
disputes was confirmed in the post-war statutes of nine provincial legislatures and of the Parliament of Canada.

I now turn briefly to look at some of the provisions for arbitration which were introduced, and especially at variations from one jurisdiction to another.

Saskatchewan is the only jurisdiction which did not introduce compulsory arbitration of disputes arising during the term of an agreement. However, it did include a statutory arbitration procedure ${ }^{7}$ which applies in those cases where the parties have agreed to arbitrate but have not provided for an arbitration procedure of their own design. In other words, the law helps to guarantee that an agreement to arbitrate shall be carried out where the parties are in default.

More commonly in Canadian jurisdictions strikes and lockouts are prohibited during the term of an agreement. Three provinces, Ontario, ${ }^{8}$ Alberta, ${ }^{9}$, and British Columbia ${ }^{10}$ make this absolute.

A slightly modified policy is found in the federal law, ${ }^{11}$ which contains the same provisions banning the strike or lockout during the life of an agreement, but permitting the parties to include in an agreement a provision that any clause in the agreement may be identified as one that may be re-opened. If it is re-opened the work stoppage is available to the parties, but only after the legally required steps in conciliation have been taken. Similar arrangements are found in Manitoba, ${ }^{12}$ Newfoundland, ${ }^{13}$ New Brunswick ${ }^{14}$ and Prince Edward Island. ${ }^{15}$

Considering that this opting-out procedure is applicable only to cases where the partie have agreed to a re-opener, it is not surprising that it has hardly ever been used. In a practical way the legal ban on strikes or lockouts during the term of an agreement is more or less complete.

Thus, in Canadian law the grievance strike or lockout cease to be bargainable issues. But what about the other half of the industrial peace

\footnotetext{
7 Saskatchewan Trade Union Act, Section 26(1).

8 Ontario Labour Relations Act, Section 63(1), 63(2), 65 \& 67.

Alberta Labour Act, Section 73(3).

10 British Columbia Labour Relations Act, Section 2(1).

1 Canada Labour Code, Sections 147(2), 163, 164, \& 180.

12 Manitoba Labour Relations Act, Section 52(3).

13 Newfoundland Labour Relations Act, Section 52(3).

14 New Brusnwick Industrial Relations Act, Section 92(3).

15 Prince Edward Island Industrial Relations Act, Section 39(2).
} 
equation, grievance arbitration? This also has been removed from the bargaining table except as to the form, and even that is, at least in some jurisdictions, an endangered species.

The Ontario law provides that:

«Every collective agreement shall provide for the final and binding settlement by arbitration, without stoppages of work, of all differences between the parties arising from the interpretation, application, administration or alleged violation of the agreement, including any question as to whether a matter is arbitrable.» ${ }^{16}$

This clause reinforces the ban on the strike and lockout, imposes arbitration, describes in general terms the scope of the arbitrator's jurisdiction and allocates to the arbitrator the power to decide on arbitrability. It does leave to the parties the form of arbitration itself. Thus the parties may use a single ad hoc arbitrator, a permanent umpire, a three-man board, or any other form they can agree to.

But there are other features of the law that deserve our attention. A weakness of any system which imposes compulsory arbitration is the problem arising if the parties fail to do what the law requires and do not write an arbitration clause. Ontario has met this problem by a statutory arbitration clause which is deemed to be included in any collective agreement which contains no arbitration clause designed by the parties in their negotiations. ${ }^{17}$

The effect of this and other provisions is that every collective agreement in Ontario has an arbitration provision even if the parties never mentioned arbitration in their negotiations. As might be expected, the statutory clause is a complex one which authorizes either party to initiate an arbitration proceeding; requires each to name a member; calls on these members to agree on a neutral chairman; empowers the minister of labour on request by either party to act by naming a member if a party is in default in appointment; or if the two nominees fail to agree on a neutral chairman, to name the chairman. It also authorizes the Labour Relations Board to amend the procedures of the negotiated arbitration clause, or of the statutory clause if deemed by the Board to be inadequate.

Several other jurisdictions have adopted policies very similar to that of Ontario although there are some variations in the legislation from jurisdiction to jurisdiction. Only a few of these variations need to be

16 Ontario Labour Relations Act, Section 82(1).

17 Ibid., Section 82(2), (3), (4). 
mentioned. A few provinces grant the parties the choice of settling grievance disputes «by arbitration or otherwise». ${ }^{18}$ There has been much speculation on the meaning of the word «otherwise». Nova Scotia has a special provision for grievance arbitration in the construction industry. It provides for very rapid action under a single arbitrator chosen by the parties or imposed in default, by the minister of labour. ${ }^{19}$

These are illustrations. They are found again and again in most of the country and they reveal the extent to which grievance arbitration has come under statutory control in general in Canada. But there are a few other illustrations of experiments which are in existence in only or a very few jurisdictions. Since some of these may be indications of future trends they must be considered.

The Nova Scotia imposition of a single arbitrator in the construction industry contracts has already been mentioned. A similar provision for a single arbitrator is imposed in the Quebec construction industry, but the law requires that the arbitrator shall be chosen at the time of negotiation of the agreement, failing which a state agency will name him. ${ }^{20}$ Ontario has gone further ${ }^{21}$. Notwithstanding any provisions in construction industry agreements for disposing of grievances, either party may refer any dispute concerning the interpretation, application, administration or alleged violation of the agreement, to the Labour Relations Board for final and binding settlement. The Board is authorized to appoint a labour relations officer who attempts to mediate the dispute. But the Board also has the authority to arbitrate the case itself.

Intervention by the state into the process of grievance dispute resolution has been greatest in British Columbia as a brief examination of that province's unique experiments will reveal. To begin with an arbitrator or arbitration board «shall... have regard to the real substance of the matters in dispute and the respective merit of the positions of the parties thereto under the terms of the collective agreement, and shall apply principles consistent with the industrial relations policy of this Act, and is not bound by a strict legal interpretation of the issue in dispute. ${ }^{22}$

Here the statute not only establishes arbitration as a legal requirement, but it also provides the arbitrator with the principles which

\footnotetext{
18 New Brunswick Industrial Relations Act, Section 55(1).

19 Nova Scotia Trade Union Act, Section 103.

20 Quebec Construction Industry Labour Relations Act, Section 30.

21 Ontario Labour Relations Act, Section 112a.

22 British Columbia Labour Code, Section 92(3).
} 
should be applied in his decision-making. Included in these is the industrial relations policy of the Act. In a sense the arbitrator is forced to interpret the law as well as the agreement. Presumably the law and its principles would take precedence over the agreement in case of conflict in industrial relations policy between the agreement and the Labour Code of British Columbia.

The same law imposes on the parties and their arbitrator the principle of just cause in dismissal or discipline cases. ${ }^{23}$ It reads in part as follows:

«Every collective agreement shall contain a provision governing dismissal or discipline of an employee bound by the agreement and that provision, or another provision, shall require that the employer have a just and reasonable cause for the dismissal or discipline or an employee...»

An opting out provision is available to the parties by agreement, for probationers.

Again I suggest the arbitrator is forced to interpret a statute. I am not a member of the legal fraternity, but I would fear that such a provision will encourage judges to hear appeals from arbitration awards on the merits.

Another clause in the law ${ }^{24}$ in effect establishes the Labour Relations Board as a labour court to hear and decide grievance disputes under an agreement. Either party, prior to the actual appointment of an arbitrator, may request the Labour Relations Board to appoint an officer to confer with the parties to assist them to settle differences, and the Board has the choices of appointing such an officer, declaring that the case is arbitrable, referring the difference back to the parties for arbitration, or acting as an arbitration board itself. However, the parties to an agreement may jointly opt out of this legal provision. In practice this is a system of mediation and arbitration and is very similar to the provision in the Ontario law for the resolution of grievances in construction.

The British Columbia Act goes further: ${ }^{25}$

"Where a difference arises during the term of a collective agreement, and, in the opinion of the board, delay has occurred in settling the difference, or the difference is a source of industrial unrest between

23 Ibid., Section 93(1).

24 Ibid., Section 96.

25 Ibid., Section $97 \& 98$. 
the parties, the board may, on the application of either party to the difference, or on its own motion, inquire into the difference, and make recommendations for settlement and, where the difference is arbitrable, order that it be immediately submitted to a specific stage or step in the grievance procedure provided under the collective agreement; or, whether the difference is arbitrable or not, request the minister to appoint a special officer.

«...an arbitration board has all the authority necessary to provide a final and conclusive settlement of a dispute arising under the provisions of a collective agreement, and, without limiting the generality of the foregoing, has authority;

(a) to make an order fixing and determining the monetary value of any injury or loss suffered by an employer, trade-union, or any other person as a result of a contravention of a collective agreement, and directing an employer, trade-union, or other person to pay to an employer, trade-union, or other person all or part of the amount of the monetary value of the injury or loss as fixed and determined by the board,

(b) to make an order directing an employer to reinstate an employee dismissed under circumstances constituting a contravention of a collective agreement,

(c) to make an order directing an employer or trade-union to rescind and rectify any disciplinary action taken in respect of an employee that was imposed under circumstances constituting a contravention of a collective agreement,

(d) to determine that a dismissal or discipline is excessive in all the circumstances of the case and substitute such other measures as appears just and equitable,

(e) to relieve, on such terms as may be just and reasonable, against any breaches of time limits or other procedural requirements set out in the collective agreement,

(f) to dismiss or reject an application or grievance, or refuse to settle a difference, where, in the opinion of the arbitration board, there has been unreasonable delay by the person bringing the application or grievance, or requesting the settlement, and the delay has operated to the prejudice or detriment of the other party to the difference, and

(g) to interpret and apply any Act intended to regulate the employment relationship of the persons bound by a collective agreement notwithstanding that its provisions conflict with the terms of the collective agreement.»

It does not require a detailed examination of this unusual legislation to realize that the parties in collective bargaining in British Columbia have largely lost control of arbitration.

The reason advanced for this experiment in med-arb involving an officer and the Labour Relations Board as well as arbitrators chosen by the parties is the dissatisfaction with arbitration expressed by the parties. The unions especially were legitimately unhappy about the 
excessive costs, the agonizing delays and in some cases poor quality of arbitration. Resolution by this public system has certainly reduced the cost since much of this is borne by the public. Undoubtedly the system is popular with the parties. In the first full year of operation (1964) 126 applications were made, 87 of these were settled by the officer, 29 resulted in orders by the Labour Relations Board, 7 were referred back to the parties for conventional arbitration and 3 were declared not arbitrable. I understand that in the last reporting year around 700 applications were filed and that the proportions of settlement by the officer, by Board ruling, by referral back to the parties, and by declaration of non-arbitrability have remained much the same.

This looks like success, and statistically on its face it is. But one must ask what may be the impact on collective bargaining and the relationship of the parties. If sixty to seventy per cent of the cases are settled by agreement through the intervention of an officer, it is legitimate to ask what is wrong with collective bargaining that most of these issues were not resolved in the grievance procedure where they should have been settled. Are the parties guilty of abdication of their responsibilities and are they protecting themselves by the med-arb system? Are frivolous cases going on the docket because this is the easy and relatively inexpensive way to avoid the hard decision? Finally are we not observing one of the fruits of compulsory arbitration of grievance disputes? These are legitimate questions to which I do not have the answers. But regardless, I express some concern about a system which has narrowed to a considerable extent the range of decision-making and freedom of the parties.

There are other Canadian experiments with arbitration which might be examined but time is limited. There is, for example, the system of adjudication (the term used in place of arbitration) of rights disputes under the Federal Public Service Staff Relations Act, in which arbitrators are appointed in accordance with statutory requirements from a limited list established under the Act, and in which the parties have no control over either the adjudicators or the adjudication process. But this is a special case of public sector employment which may have its own peculiarities which make the usual employer and union prerogatives inoperative. I withhold judgement.

But there is one more experiment which flows directly from the compulsory arbitration and no work-stoppage policy of Canadian legislation which is worth exploring. I refer to the redundancy problem related to industrial conversion or technological change. Because the law prohibits work stoppages during the term of an agreement, and 
imposes arbitration for rights disputes arising during this closed period, the parties may be locked into an agreement when change is creating serious fears and tensions which, because there is no legitimate way to renegotiate the terms of the agreement, may lead to wildcat strikes and other disruptions. Several Canadian jurisdictions have attempted to resolve this problem by an awkward procedure of re-opening the agreement under certain circumstances. Since the Manitoba provision is perhaps the most extreme I will use it as an illustration. ${ }^{26}$ Briefly an employer bound by a collective agreement is required to give 90 days notice of any proposed technological change that is likely to affect the terms and conditions, or the security, of employment of a significant number of employees in the unit or to alter significantly the basis upon which the agreement was negotiated. This notice in writing to the bargaining agent must state the nature of the proposed change, the proposed date, the approximate number and type of employees likely to be affected, and the effect the change is likely to have on the terms and conditions, or security, of employment or the alteration that is likely to be made to the basis upon which the agreement was negotiated. Such a notice opens the door to a union request for bargaining and provides for the termination of the agreement either at the expiry date or 90 days after the employer notice, whichever is the earlier. However, an employer may submit to arbitration the question of a significant number who may be affected, or whether the proposed changes will alter significantly the basis of the collective agreement.

I am not sure whether an arbitrator confronted with this kind of sooth-saying should indulge in prayer or coin tossing. I do suggest, however, that a simpler solution might have been to repeal both the prohibition on the work stoppage and the imposition of rights dispute arbitration. Surely the bargaining table is the appropriate forum for the battle over management's degree of responsibility in the technological change and redundancy issue. Historically this issue has been the cause of some very bitter controversy in Canada. I suspect it might have been more successfully handled had the process not been constrained by compulsory arbitration features of the law, with the questions of the work stoppage and redundancy both being on the bargaining table.

More illustrations of extensive public intervention in the arbitration process could be recited. But those already noted indicate that much of the innovation in arbitration procedure in Canada is the result of state

26 Manitoba Labour Relations Act, Section 72, 73 \& 74. 
action. This public presence was noted by the Federal Task Force on Labour Relations in 1969. ${ }^{27}$

Conventional wisdom in the United States looks upon the arbitration of grievances as an action in a bilateral system of industrial relations. The parties may use it or not depending on the agreement they reach. But in Canada the industrial relations system has much more of a multilateral character. The state has intruded into the process much more than in the United States. The law requires industrial peace after an agreement has been signed. The law requires arbitration to preserve the peace. In some jurisdictions statutory law lays down the procedures of arbitration and even includes the principles and public policies which must be respected by the arbitrators and the parties. The Canadian industrial relations system features a high degree of employer determination, trade union participation, collective bargaining and government involvement in a number of capacities.

I do not propose to go back in an euphoric and nostalgic trip to the sentiments of the early greats among the arbitrators such as Taylor, Witte, Shulman, and others. Times have changed and so has arbitration, yet certain basic approaches may have lasting merit. A Canadian member of the Academy in 1970 spoke as follows:

«Surely the proper way for continued development is to have more work done by the partisan parties in arbitration. The genius of the system has always been its consensual nature and the fact that the parties agreed together on the decision-maker and the process which brought the dispute to him. ${ }^{28}$

It seems to me that public policy and regulation in Canada are inexorably undermining the position of management and labour in both the freedom of choice of arbitrators and control of the process itself. Canadian unions and employers have never shown much evidence of the innovative experimentation of their American counterparts in devising new and better forms of arbitration. My thesis is that compulsions coming out of the second world war period are partly responsible. But intervention is like an exothermic chemical reaction - once started it fuels itself. Over all hangs the shadow of arbitration courts.

Let me close with an apology. This paper could leave the impression that I have come to certain conclusions which are critical of the

27 Canadian Industrial Relations, Report of the Task Force on Labour Relations, Ottawa Privy Council Office, 1969.

28 Earl Palmer, abridgement of a talk given to the Personnel Association of Toronto, Canadian Industrial Relations and Personnel Development, Toronto, March, 1970, p. 6004. 
Canadian approach to grievance arbitration and that $I$ have not proven my case. That is correct. But my justification is that I wish to open up a controversy which has not yet excited the interest of research scholars. In doing so, I have indicated some impressions which experience and observation have brought to my mind. If research should prove that I am right, Canadians should take another look at their experiments in state intervention in grievance arbitration. If, however, careful study should refute my criticism, Americans might find it profitable to review their policies and indeed much of the revealed doctrine of labour relations in the private sector.

\title{
L'INDUSTRIE QUÉBÉCOISE DE LA CONSTRUCTION ET SES PROBLÈMES
}

\author{
GÉRARD HÉBERT
}

Je me propose dans le présent exposé de toucher aux trois points suivants: 1 . les structures de négociation dans la construction, 2 . le règlement du placement au Québec, et 3. la mobilité des travailleurs de la construction.

\section{LES STRUCTURES DE NÉGOCIATION}

La négociation par métier a toujours été et demeure pratique courante parmi vos unions. Elle correspond à une tradition séculaire, et elle

Montréal.

HÉBERT, G., professeur, École de relations industrielles, Université de

** Le secrétariat canadien du Département des métiers de la construction (F.A.T.-C.O.I.) a organisé, les 17 et 18 juillet derniers, un premier congrès canadien, qui réunissait les représentants des conseils provinciaux et régionaux des métiers de la construction ainsi que ceux des différentes unions internationales des métiers de la construction.

Le congrès, qui doit se réunir tous les deux ans, parle au nom des 400,000 travailleurs canadiens de la construction. Le nouveau conseil canadien est composé d'un représentant international canadien de chacune des quinze unions et du secrétaire exécutif du Bureau canadien. Ils n'ont pas été élus, mais nommés par le président du Département des métiers de la construction (F.A.T.-C.O.I.). Le congrès était aussi présidé par le président du Département.

Le professeur Hébert était l'un des quelques invités qui ont adressé la parole aux participants du congrès. 